\title{
Pemberdayaan dan usaha peningkatan ekonomi suku Talang Mamak di kawasan Taman Nasional Bukit Tiga Puluh melalui budidaya Kelulut (Heterotrigona itama)
}

\author{
Avry Pribadi*1, Andhika Silva Yunianto', Nur Hajjah², \& Fonda Amelia Sarah ${ }^{2}$ \\ ${ }^{1}$ Peneliti pada Balai Litbang Teknologi Serat Tanaman Hutan, Kuok \\ 2Penyuluh Kehutanan pada Balai Taman Nasional Bukit Tiga Puluh, Rengat \\ *avrypribadi@gmail.com
}

\begin{abstract}
Abstrak. Taman Nasional Bukit Tiga Puluh (TNBT) selain merupakan habitat bagi flora dan fauna juga menjadi tempat tinggal bagi masyarakat Talang Mamak. Kegiatan pemberdayaan masyarakat Talang Mamak di dalam kawasan TNBT diperlukan untuk meningkatkan kesejahteraan mereka sebagai upaya menekan deforestasi yang salah satunya melalui budidaya kelulut. Kegiatan-kegiatan yang dilakukanantara lain survey pendahuluan, pembentukkan Kelompok Tani Hutan (KTH), pemberian pelatihan, pemberian bantuan koloni kelulut dan peralatan pelengkapnya, pendampingan, pemasaran, dan monev. Hasil menunjukkan bahwa pada akhir tahun pertama produksi madu menunjukkan peningkatan. Bahkan KTH Bomban Berduri mengalami kenaikan produksi madu sebesar 85,5\% jika dibandingkan dengan hasil panen madu pada caturwulan kedua tahun 2019. Hal serupa juga terjadi pada KTH-KTH lainnyaseperti Batu Berdiri dan JelemuBengayauan. Hal ini menunjukkan bahwa kegiatan pemberdayaan masyarakat melalui budidaya kelulut telah menunjukkan hasil meskipun masih dalam jumlah yang sedikit. Akan tetapi, terdapat beberapa permasalahan dalam pengelolaan kelulut, yaitu kurang fokusnya masyarakat, pemasaran, dan kurangnya perawatan yang dilakukan oleh masyarakat terhadap koloni lebah kelulut.
\end{abstract}

Kata kunci: TN Bukit Tiga Puluh, Talang Mamak, Kelulut, pemberdayaan

\begin{abstract}
Bukit Tiga Puluh National Park is not only a place for wildlife but also a home for Talang Mamak tribe (a local and native tribe lives inside the National Park). Furthermore, to support Talang Mamak, an empowerment is critically needed. Meliponiculture is one form of empowerment activity provided by Thirty Hills National Park. There are many steps to do this empowerment activities, namely, conducting preliminary survey, forming groups for each sub villages, training, giving grant beekeeping equipments, assistance, detailing in marketing, and evaluating. Results showed that in the first year after training, honey production increased $85.5 \%$ in the third quarter compare to honey produced in the second quarter. Other groups, such as KTH Batu Berdiri and KTH JelemuBengayuan, also gave similar tendency. These results also revealed that the empowerment activity by doing meliponiculture had given positive contribution for Talang Mamak even though it`s production is still not much. Nevertheless, there are some obstacles when doing this meliponiculture. For instances, sometimes, Talang Mamak people is less focus when facing problems. Other problems are that they cannot determine their market target and there is no maintenance toward the stingless bees' colonies.
\end{abstract}

Keywords: Thirty Hills National Park, Talang Mamak Tribe, Stingless Bees, local community empowerment

To cite this article: Pribadi, A., A. S. Yunianto., N. Hajjah., \& F. A. Sarah. 2020. Pemberdayaan dan usaha peningkatan ekonomi suku Talang Mamak di kawasan Taman Nasional Bukit Tiga Puluh melalui budidaya Kelulut (Heterotrigona itama). Unri Conference Series: Community Engagement 2: 98-105.

https://doi.org/10.31258/unricsce.2.98-105

(C) 2020 Authors

Peer-review under responsibility of the organizing committee of Seminar Nasional Pemberdayaan Masyarakat 2020 


\section{PENDAHULUAN}

Bukit Tiga Puluh merupakan Hutan Lindung Haposipin di wilayah Riau dan Hutan Lindung Singkati Batang Hari di wilayah Jambi, serta Hutan Produksi Terbatas yang telah diubah fungsi dan ditunjuk menjadi sebuah taman nasional pada tahun 1995 dengan SK Menteri Kehutanan No. 539/Kpts-II/1995 dan selanjutnya ditetapkan dengan SK Menteri Kehutanan No. 6407/Kpts-II/2002 dengan luas 144.223 ha (TNBT, 2017). Secara ekologis, Taman Nasional Bukit Tiga Puluh (TNBT) merupakan kawasan dengan tipe ekosistem hutan tropis daratan rendah (low land tropical rain forest) (Samsoedin and Pramono, 1996). Berdasarkan studi yang dilakukan oleh Antoko et al. (2006) menunjukkan bahwa TNBT masih memiliki keanekaragaman dalam kategori tinggi. Selain merupakan habitat dari berbagai jenis flora dan fauna langka dan dilindungi, kawasan TNBT juga merupakan tempat tinggal dan hidup beberapa komunitas suku pedalaman seperti suku Talang Mamak, suku Kubu (Anak Rimba), dan suku Melayu Tua (TNBT, 2017).

Permasalahan utama yang ditemui oleh masyarakat suku Talang Mamak diantaranya adalah tingkat kesejahteraan yang masih rendah karena masih mengandalkan hasil dari alam (ekstraktif) seperti damar, karet, kelukup, jernang, kemenyan, dan kopi yang jumlah produksi sangat terbatas (Melyana et al., 2015). Hal ini dikhawatirkan akan menjadi factor pemicu terjadinya tekanan terhadap hutan berupa maraknya kegiatan illegal logging. Menurut TFCA-Sumatera (2016), ancaman utama TNBT selain illegal logging yang terjadidi kawasan Teluk Keritang - Simpang Datai, Sungai Akar, Rantau Langsat, Usul, Alim, Puntianai, Suo-Suo, dan Pemayungana dalah maraknya perburuan liar seperti harimau, murai batu, tiung, dan labi-labi, dan perladangan berpindah yang dilakukan masyarakat rata-rata 1 s.d 2 ha/tahun. Oleh sebab itu sebagai salah satu kewajiban Balai TNBT selain mengamankan kawasannya adalah memberdayakan masyarakat lokal yang berada di dalam kawasan dengan tujuan untuk mencari jalan keluar terhadap masalah utama yang terjadi pada suku Talang Mamak untuk mencegah terjadinya kerusakan hutan melalui cara yang lebih persuasif yang salah satunya adalah melalui kegiatan pemberdayaan dengan memanfaatkan potensi lokal yang belum termanfaatkan seperti budidaya kelulut. Kegiatan pemberdayaan masyarakat ini dimaksudkan sebagai kegiatan yang sengaja dilakukan pemerintah untuk memfasilitasi masyarakat lokal dalam mencari masalah, merencanakan, memutuskan, dan mengelola sumber daya yang dimiliki di lingkungannya sehingga pada akhirnya mereka memiliki kemampuan dan kemandirian secara ekonomi, sosial, dan ekologi secara berkelanjutan (Noor, 2018). Sebelumnya, Balai TNBT telah beberapa kali melakukan kegiatan pemberdayaan seperti budidaya jernang dan kelukup, akan tetapi hasil yang dipeoleh belum mampu memenuhi kebutuhan masyarakat Talang Mamak. Oleh karena itu, pada tahun 2018, kegiatan budidaya kelulut mulai diperkenalkan pada masyarakat Talang Mamak tersebut. Kegiatan ini merupakan kerjasama antara Balai TNBT dengan Balai Litbang Teknologi Serat Tanaman Hutan (BP2TSTH).

Kelulut (Heterotrigonaitama) merupakan kelompok lebah tidak bersengat yang memiliki karakter untuk hidup secara sosial dalam satu koloni dan berhabitat di bambu, batang kayu, dan tanah (Erwan \& Yanuartati, 2012; Michener, 2013). Kelompok lebah ini terdistribusi di daerah tropis dan subtropis seperti Australia, Amerika Selatan, Asia Selatan, dan Asia Tenggara (Eltz, 2001). Jenis H. itama merupakan salah satu jenis kelulut yang dominan ditemukan di daerah pulau Sumatera (Purnomo et. al., 2012). Sebenarnya produk kelulut yang utama $\mathrm{H}$. itama adalah propolis yang dapat dimanfaatkan sebagai bahan kosmetik dan obat-obatan. Lebih lanjut, studi yang dilakukan oleh Pribadi (2020) menunjukkan bahwa produksi propolis mentah pada $H$. itama lebih efektif jika menggunakan propolis trap yang terbuat dari kawat streamin yang adopsi propolis trap yang ada pada Apis mellifera. Propolis mengandung senyawa yang terdiri atas senyawa antibiotic, flavonoid, mineral, vitamin, dan enzim (Mello \& Hubinger, 2012). Hasil lain dari kelulut adalah madu. Berdasarkan studi yang dilakukan oleh Kek et al. (2018) dan Shamsudin et al. (2019) menunjukkan bahwa kandungan senyawa fenolik madu kelulut yang diternakkan di perkebunan Gelam mencapai 4 kali lipat dibanding madu lebah ternak dan lebih dari 100 kali lipat untuk kemampuan antioksidannya. Madu kelulut memiliki karakter yang berbeda dengan madu hutan (Apisdorsata) yaitu memiliki kadar air yang lebih tinggi dibandingkan madu hutan (A. dorsata) di Riau dan Sumatera Barat yang berkisar 23,83\% s.d 26.7\% (Pribadi and Wiratmoko, 2019; Wiratmoko and Pribadi, 2020). Oleh sebabitu, produk madu kelulut memiliki prospek yang sangat bagus untuk dikembangkan terutama di masa pandemic covid 19.

Tujuan penulisan adalah untuk menginformasikan tentang proses kemajuan dan perkembangan usaha untuk menyebarluaskan ilmu pengetahuan dan teknologi tentang budidaya kelulut kepada masyarakat Talang Mamak. Sebagai informasi, sebelum kegiatan pemberdayaan ini dilakukan, baik masyarakat yang tinggal di sekitar kawasan (zona penyangga) yang mayoritas meruapakan pendatang maupun masyarakat Talang Mamak yang tinggal di zona tradisional belum mengetahui sama sekali bagaimana berbudidaya kelulut. 


\section{METODE PENERAPAN}

1. Lokasi dan waktu pelaksanaan kegiatan

Kegiatan pemberdayaan masyarakat ini dilakukan pada lima kelompok masyarakat suku Talang Mamak yang berada di zona tradisional dan penyangga, yaitu Tualang, Bengayouan, Air Bomban, Nunusan, dan Sadan. Pelaksanaan kegiatan dilakukan mulai tahun 2018 s.d 2020.

2. Prosedur pelaksanaan

Kegiatan ini dibagi menjadi beberapa tahapan, yaitu:

1) Kegiatan pendataan kebutuhan pelatihan lebah madu

2) Kegiatan pelatihan dan pembentukkan Kelompok Tani Hutan (KTH)

3) Kegiatan pemberian bantuan koloni lebah dan perlengakapan pendukungnya

4) Kegiatan pendampingan

5) Kegiatan pemasaran

6) Kegiatan monitoring dan evaluasi.

3. Parameter keberhasilan yang diukur

1) Jumlah produksi madu yang berhasil diperoleh

2) Estimasi jumlah pendapatan yang diperoleh

4. Analisa tingkat keberhasilan

Data yang diperoleh dianalisa secara deskriptif kuantitatif dan kualitatif terhadap jumlah produksi madu dan estimasi jumlah pendapatan yang diperoleh sehingga akan diperoleh gambaran umum mengenai tingkat keberhasilan kegiatan pemberdayaan masyarakat yang pada studi ini dilihat dari estimasi perubahan pendapatan (ekonomi) masyarakat sasaran yang dibandingkan dengan jika tidak dilakukannya kegiatan pemberdayaan masyarakat melalui lebah kelulut.

\section{HASIL DAN KETERCAPAIAN SASARAN}

Pemberdayaan masyarakat suku Talang Mamak merupakan suatu kegiatan yang memiliki beberapa tujuan, yaitu usaha untuk menyebarluaskan ilmu pengetahuan dan teknologi kepada masyarakat dan juga untuk memberikan nilai tambah bagi masyarakat suku Talang Mamak terutama dalam bidang ekonomi. Balai TNBT telah banyak melakukan kegiatan untuk memberdayakan masyarakat suku Talang Mamak baik yang berada di zona penyangga dan tradisional, antara lain melalui peningkatan kapasitas KTH berupa pelatihan budidaya rotan jernang, kelukup, pinang, dan ternak sapi. Selainitu, Balai TNBT juga telah memberikan bantuan berupa bibit kelukup sebanyak 3000 bibit dan 4 ekor sapi yang bertujuan untuk pengembangan ekonomi masyarakat (TNBT, 2017). Selain bantuan berupa materi, Balai TNBT juga menginisiasi pembentukan KTH-KTH di dusun-dusun lain yang salah satunya bertujuan untuk memudahkan koordinasi dan peningkatan kapasitas mereka. Hal ini terlihat dari meningkatnya jumlah KTH yang pada tahun 2017 hanya berjumlah 4 meningkat menjadi delapan KTH pada 2019 dan ada kemungkinan akan terus bertambah.

Tujuan kegiatan pemberdayaan masyarakat tersebut adalah untuk meningkatkan kapasitas kemampuan masyarakat suku Talang Mamak yang berada pada zona tradisional untuk mendapatkan akses ekonomi berupa peningkatan pendapatan. Akan tetapi, menurut sebagian masyarakat suku Talang Mamak, kegiatan ekstraktif berupa pengambilan jernang, kelukup, dan damar belum dapat memenuhi keinginan masyarakat suku Talang Mamak dikarenakan jumlahnya yang semakin sedikit. Di sisi lain, berdasarkan hasil identifikasi potensi yang berada di zona tradisional menunjukkan bahwa salah satu jenis potensi lain yang dapat dikembangkan adalah jenis kelulut (H. itama). Hal ini didukung oleh studi Sakagami et al. (1990) yang menunjukkan bahwa jenis H. itama merupakan salah satu jenis yang tersebar di pulau Sumatera. Selainitu, studi lain yang dilakukan oleh Kerisna et al. (2019) menunjukkan bahwa jenis kelulut menyukai temperatur lingkungan $26^{\circ} \mathrm{C}-33^{\circ} \mathrm{C}$, kelembaban 60\%-82\% dan ketinggian tempat 14 mdpl-131 mdpl yang didominasi oleh tegakan dari kelompok Dipterocarpa yang merupakan vegetasidominan di kawasan TNBT. Oleh sebabitu, untuk mendukung kegiatan pemberdayaan masyarakat suku Talang Mamak di zona tradisional dan penyangga maka sejak tahun 2018 mulai diperkenalkan kegiatan budidaya kelulut. Kegiatan pemberdayaan budidaya kelulut dilakukan oleh Balai TNBT bekerjasama dengan Balai Litbang Teknologi Serat Tanaman Hutan. Rangkaian kegiatan ini adalah:

1. Kegiatan pelatihan dan pembentukkan Kelompok Tani Hutan (KTH)

Kegiatan ini merupakan kegiatan inti yang berisikan tentang pelatihan baik teori dan praktek tentang budidaya lebah madu, mulai dari mengenal jenis lebah, biologi lebah, peralatan dan perlengkapan budidaya lebah, tanaman pakan, manajemen lebah, hama dan penyakit, produk-produk perlebahan, teknis 
pemanenan, dan pemasaran. Sedangkan pada tahun 2019, kegiatan pelatihan ditambah dengan materi diversifikasi produk perlebahan (Gambar 1).
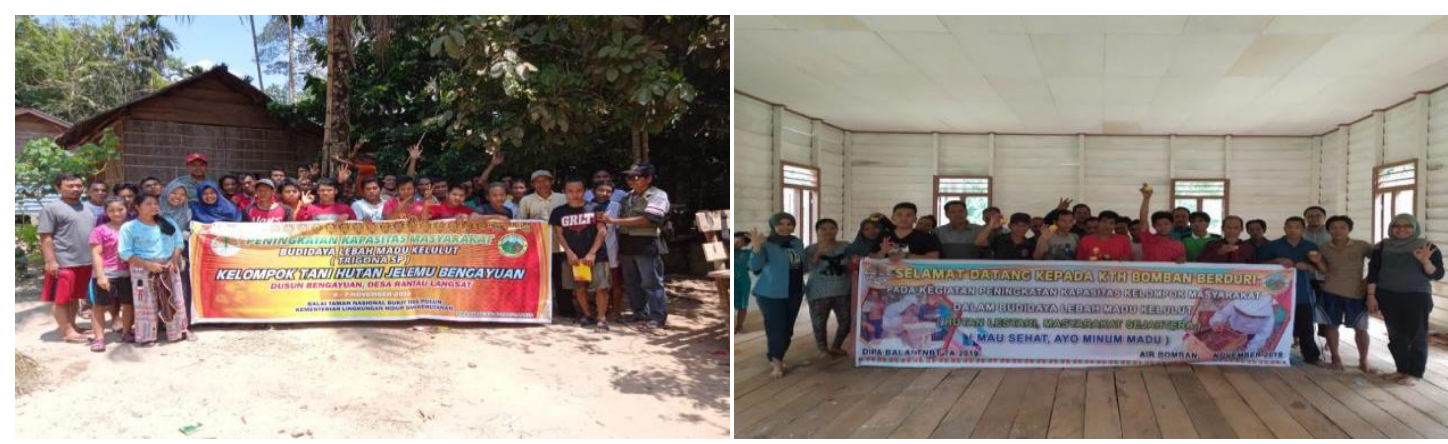

Gambar 1. Kegiatan pelatihan budidaya kelulut di Bengayauan dan Air Bomban

2. Kegiatan pemberian bantuan koloni lebah dan perlengakapan pendukungnya

Pemberian bantuan berupa koloni lebah kelulut dilakukan dengan memperhitungkan jumlah anggota setiap KTH (Tabel 1).

3. Kegiatan pendampingan

Kegiatan ini dilakukan pasca pelatihan yang bertujuan untuk mengantisipasi jika dalam berkegiatan budidaya lebah madu terdapat permasalahan. Masalah utama yang dijumpai adalah teknis budidaya diantaranya adalah belum menghasilkan madu dan koloni belum mencapai atau naik kekota keram madu (topping).

4. Kegiatan pemasaran

Kegiatan ini dilakukan untuk memasarkan dan mempromosikan hasil panen utama berupa madu kelulut ke pasar. Hasil menunjukkan pada tahun 2018 s.d 2019 hampir seluruh masyarakat suku Talang Mamak belum mengetahui bagaimana cara memasarkan produk madu sehingga mereka cenderung untuk menunggu di dusun dan menunggu pihak Balai TNBT mengambil dan dapat dijual melalui koperasi pegawai TNBT. Atau dengan kata lain, mereka masih belum mengerti sama sekali bagaimana cara memasarkan hasil panen mereka.

Tabel 1. Jumlah bantuan yang diberikan oleh Balai TNBT dalam rangka kegiatan pemberdayaan masyarakat melalui budidaya kelulut yang diterima oleh lima KTH di zona tradisional.

\begin{tabular}{llccccc}
\hline & & \multicolumn{5}{c}{ Nama KTH / Dusun } \\
\cline { 3 - 7 } No & Paket Bantuan & $\begin{array}{c}\text { Jelemu } \\
\text { Bengayouan } \\
\text { (Bengayouan) }\end{array}$ & $\begin{array}{c}\text { Tualang } \\
\text { Sejahtera } \\
\text { (Tualang) }\end{array}$ & $\begin{array}{c}\text { Kasih } \\
\text { Alam } \\
\text { (Nunusan) }\end{array}$ & $\begin{array}{c}\text { Batu } \\
\text { Berdiri } \\
\text { (Sadan) }\end{array}$ & $\begin{array}{c}\text { Bomban } \\
\text { Berduri }\end{array}$ \\
(Air Bomban) \\
\hline 1 & Koloni kelulut & 15 & 15 & 15 & 15 & 15 \\
2 & Kotak topping & 25 & 25 & 25 & 25 & 25 \\
3 & APD/ masker & 5 & 5 & 5 & 5 & 5 \\
4 & Alat panen & 5 & 5 & 5 & 5 & 5 \\
5 & Botol kemasan & 50 & 50 & 50 & 50 & 50 \\
\hline
\end{tabular}

5. Kegiatan monitoring dan evaluasi

Kegiatan ini dilakukan untuk mengevaluasi kegiatan untuk mencari permasalahan dan kekurangan yang dihadapi sewaktu pelaksanaan kegiatan sebagai perbaikan untuk pelaksanaan kegiatan berikutnya. 
Kegiatan pemberdayaan masyarakat sukuTalang Mamak di zona tradisional ini telah berlangsung selama 3 tahun. Setelah dilakukan pelatihan budidaya kelulut pada akhir tahun 2018, secara umum produksi madu pada tiap KTH sampai pada caturwulan kedua cenderung mengalami penurunan kecuali di KTH Bomban Berduri. Sebagai contoh, KTH Jelemu Bengayouan mengalami penurunan sebesar $75 \%$ pada caturwulan kedua (Gambar 1). Beberapa permasalahan yang dijumpai pada caturwulan kedua ini adalah:

1. Para anggota KTH belum menguasai tehnik budidaya sehingga ketika ditemukan masalah yang bersifat teknis cenderung untuk menghindar sehingga aspek perawatan kelulut terlupakan.

2. Belum adanya kejelasan mengenai pemasaran madu pada periode caturwulan pertama membuat anggota KTH cenderung "kurang bersemangat" dalam melanjutkan budidaya kelulut. Hal ini terlihat dari hasil monitoring dan evaluasi yang menunjukkan bahwa hanya beberapa orang tersisa yang masih merawat koloni kelulut.

Berdasarkan hasil monitoring tersebut menunjukkan bahwa permasalahan sebenarnya adalah lebih bersifat non teknis, yaitu kurangnya partisipasi anggota KTH dalam berbudidaya kelulut. Meskipun kondisi lingkungan mendukung untuk berbudidaya kelulut karena masih berupa kawasan berhutan, partisipasi anggota KTH merupakan hal yang penting dalam kesuksesan berbudidaya kelulut.

Fenomena penurunan produksi madu yang terjadi pada caturwulan kedua menjadi dasar bagi Balai TNBT untuk kembali melakukan kegiatan pelatihan lanjutan. Pada pelatihan lanjutan ini memfokuskan pada kegiatan perbaikan aspek teknis budidaya kelulut dan pengenalan diversifikasi produk-produk turunan lebah madu. Pada kegiatan perbaikan aspek teknis budidaya kelulut, kegiatan lebih ditekankan pada pencarian solusi terhadap permasalahan yang ada. Kegiatan yang bersifat praktek lebih ditekankan pada aspek teknis ini. Misalnya adalah permasalahan kotak eram (topping) yang belum dihuni dan berisi kantung madu dapat diatasi dengan melakukan praktek pemancingan dan pemotongan log asal (Gambar 2). Permasalahan lain adalah bagaimana teknis memecah koloni dan mendapatkan koloni dari alam tanpa menebang pohon. Pada aspekpengenalandiversifikasiproduk, para anggota KTH diperkenalkan dengan berbagai produk turunan lebah madu yang bahannya berasal dari kelulut yang mereka ternakan, seperti sabun propolis, sabun madu, dan madu formula. Tujuan dari kegiatan ini pada jangka panjang adalah untuk menjadikan KTH-KTH ini tidak hanya bergantung pada produk berupa madu, tetapi juga mampu memberikan nilai tambah sehingga akan lebih mudah dikenal oleh masyarakat umum.

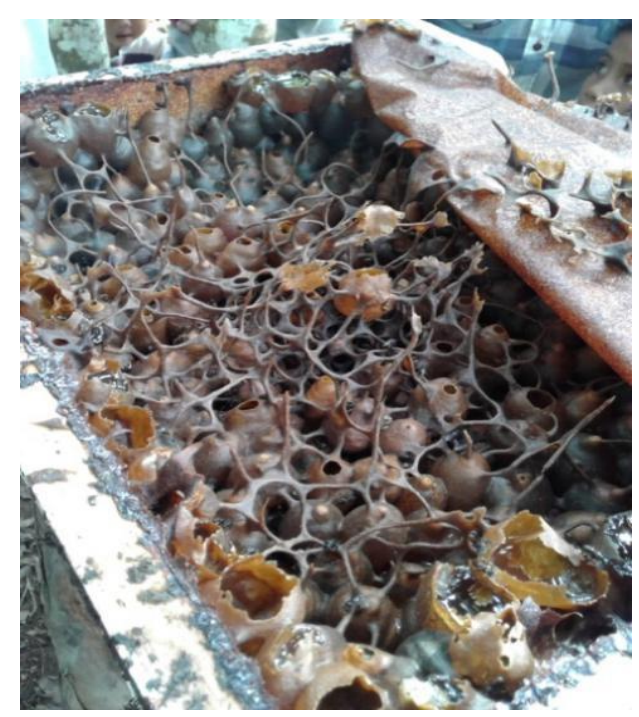

Gambar 2. Kantungmadu pada kotakerammadu (topping) di salah satukolonikelulut pada dusunBengayauan 
Kegiatan pelatihan kedua yang dilakukan pada bulan Oktober 2019 ini memberikan hasil yang baik. Hal ini terlihat dari produktivitas panen madu kelulut yang meningkat pada caturwulan ketiga. Peningkatan tertinggi terjadi di KTH Bomban Berduri yang mengalami kenaikan sebesar 85,5\% jika dibandingkan dengan hasil panen madu pada caturwulan kedua (Gambar 3). Hal ini menunjukkan bahwa kegiatan pelatihan kedua ini efektif dalam memberikan pengaruh terhadap meningkatnya produksi madu kelulut. Hal ini didukung dengan meningkatnya promosi yang dilakukan oleh Balai TNBT. Kecenderungan positif ini terus terjadi pada caturwulan pertama di tahun 2020 di hampir seluruh KTH kecuali KTH Batu Berdiri yang mengalami penurunan. Sedangkan KTH Bomban Berduri belum diperoleh data panen madu kelulut pada periode ini (Gambar 3).

Balai TNBT menerapkan mekanisme satu harga untuk menyamakan harga madu kelulut yang diproduksi oleh KTH-KTH binaan mereka. Pada tahun 2019, pihak Balai TNBT menetapkan harga Rp 50.000,00 untuk satu botol madu ukuran 200 gram. Pada tahun pertama, KTH Batu Berdiri menjadi KTH yang berhasil memperoleh pendapatan terbanyak dibanding dengan KTH-KTH lainnya, yaitu sebesar Rp 3.587.500,00. Hal yang menarik terjadi pada KTH Jelemu Bengayouan yang menunjukkan peningkatan pendapatan yang signifikan. Pada tahun 2019, KTH ini hanya berhasil mengumpulkan pendapatan sebesar Rp 550.000,00 dan mengalami peningkatan lebih dari tiga kali lipat hanya pada caturwulan pertama tahun 2020, yaitu sebesar Rp 1.750.000,00. Hal ini menunjukkan bahwa perkembangan budidaya kelulut mengalami perkembangan yang sangat baik jika dilihat dari jumlah penghasilan yang diperoleh. Selain itu, KTH Bomban Berduri juga menunjukkan hasil panen madu kelulut tertinggi dibandingkan dengan KTH lainnya. Hal inilah yang menjadikan KTH Bomban Berduri sebagai role model bagi KTH lainnya dalam mengelola budidaya lebah kelulut.

Meskipun jumlah pendapatan terlihat kecil, akan tetapi hal ini memberikan gambaran dan perubahan sikap masyarakat suku Talang Mamak. Selama ini, masyarakat suku Talang Mamak lebih banyak bergantung pada hasil alam melalui usaha pemungutan hasil alamnya dan hanya sedikit mengenal kegiatan berladang seperti bercocok tanam padi dan ketela pohon. Pada awalnya, melakukan budidaya kelulut merupakan hal yang tidak pernah terpikir untuk dilakukan karena untuk kebutuhan madu mereka dapat dipenuhi dengan cara berburu madu hutan sialang (Apis dorsata) meskipun jumlahnya terbatas dan semakin menurun serta kegiatan tersebut hanya terbatas pada beberapa orang yang memiliki kemampuan tertentu dan ada kecenderungan produksinya terus menurun sebagai akibat dari luas hutan yang semakin berkurang. Terbatasnya jumlah produksi madu sialang berkorelasi positif dengan keberadaan hutan (Pribadi, 2020).

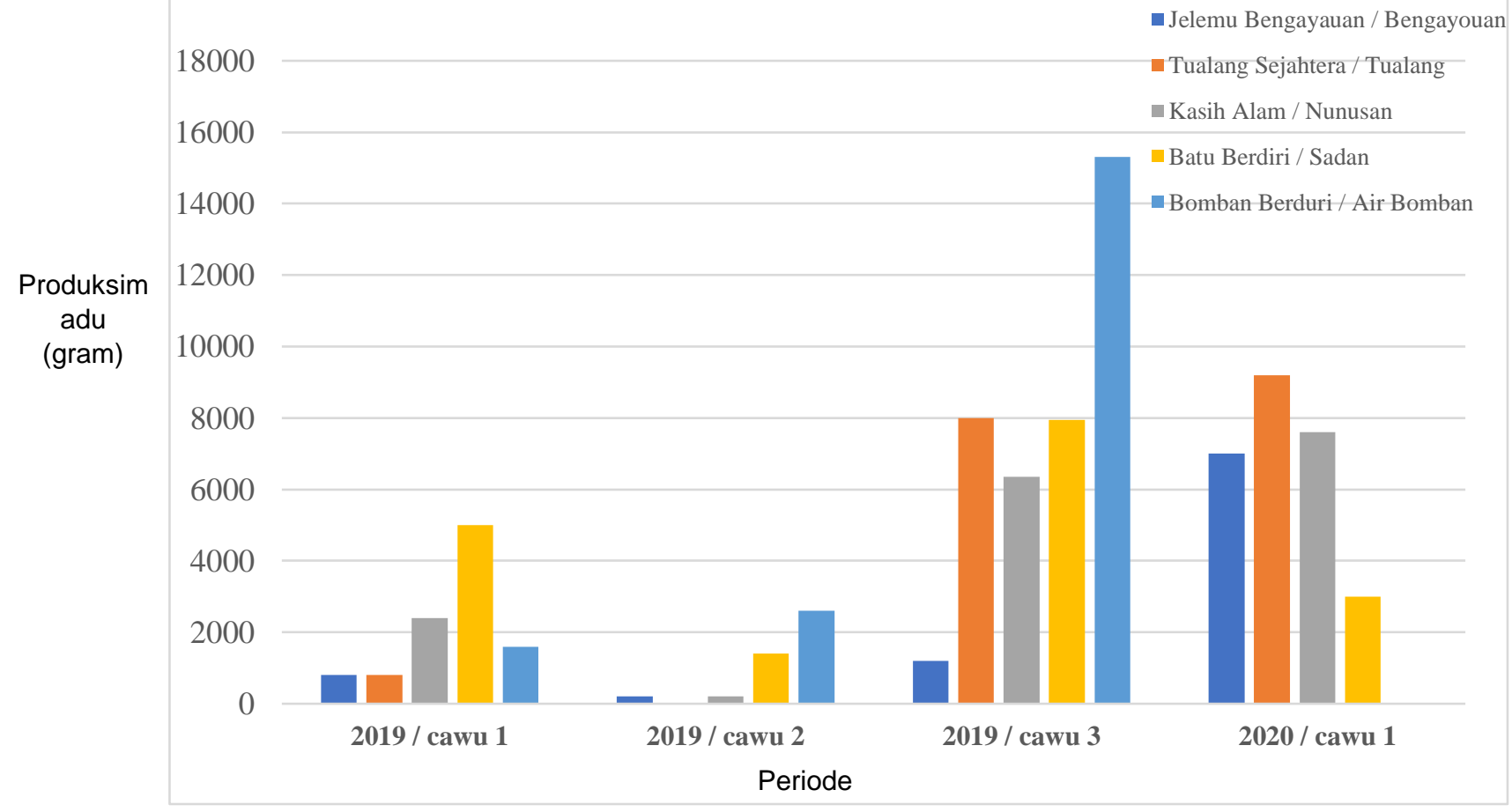

Gambar 3. Grafikperkembanganproduksimadukelulutselamaperiode 2019 s.d 2020 
Ketika kegiatan budidaya kelulut ini mulai menunjukkan hasil, hal ini menjadi pemicu dan meyakinkan mereka bahwa ada alternatif pendapatan lain yang apabila ditekuni akan memberikan hasil yang baik dan tidak perlu menuntut mereka untuk masuk ke hutan terutama ketika produksi jernang dan kelukup yang semakin sedikit. Hal lain yang mendukung bahwa kegiatan budidaya kelulut ini menjadi salah satu kegiatan pemberdayaan yang berhasil adalah adanya keinginan dari tiga dusun Talang Mamak lainnya yang juga berkeinginan untuk dilatih tentang berbudidaya kelulut, yaitu dusun Datai, dusun Suit, dan dusun Talang Tanjung.

Keberadaan budidaya kelulut ini mampu memberikan tambahan penghasilan di luar yang sudah mereka dapatkan dari alam baik dalam jangka pendek maupun panjang dengan memanfaatkan jasa lingkungan yang disediakan oleh hutan. Kemudahan dalam perawatan, harga madu yang relatif lebih mahal, dan tidak perlu menunggu lama dalam memperoleh hasil menjadi tiga alasan utama kenapa masyarakat Talang Mamak lebih memilih budidaya kelulut. Akan tetapi, kegiatan ini memiliki beberapa permasalahan, diantaranya adalah:

1. Beberapa masyarakat Talang Mamak mulai mencari sendiri koloni kelulut di hutan sehingga dikhawatirkan mereka akan menebang pohon hanya untuk mendapatkan koloni kelulut.

2. Pemasaran madu kelulut masih terkendala oleh jarak, karena untuk menjual mereka harus keluar dusun dengan menggunakan sampan yang membutuhkan biaya tidak sedikit.

3. Kurangnya kebiasaan untuk merawat dan menjaga baik peralatan dan perlengkapan maupun koloni kelulut hasil dari bantuan Balai TNBT sehingga ada beberapa peralatan terutama alat panen madu kelulut mengalami kerusakan dan koloni yang kabur karena diserang oleh semut, rayap, atau hama yang lainnya.

Beberapa tantangan dalam kegiatan pemberdayaan masyarakat ini adalah lokasi dusun yang jauh dari akses kendaraan karena sebagian besar harus menggunakan sampan bermesin yang sangat bergantung pada debit sungai Gangsal. Tantangan kedua adalah sebagian besar masyarakatnya yang tidak bisa baca dan tulis sehingga penyampaian materi budidaya lebah kelulut lebih ditekankan pada kegiatan yang bersifat dialog dan praktek, sedangkan pemberian materi dengan menggunakan media pembelajaran berupa Ms. Power Point sangat sedikit diberikan. Tantangan selanjutnya adalah tingkat antusias masyarakat Talang Mamak yang masih rendah. Hal ini terlihat ketika dilakukan proses pembelajaran masih banyak peserta pelatihan yang terlihat malu dan kurang aktif dalam mengikuti proses pembelajaran. Tantangan keempat adalah kurang fokusny masyarakat dalam melakukan budidaya kelulut. Hal ini terlihat dari beberapa bulan terakhir banyak koloni yang tidak terawat dikarenakan banyak masyarakat yang mencari damar ke dalam hutan. Meskipun demikian, setelah 1 tahun melakukan kegiatan ini, tingkat partisipasi masyarakat meningkat karena mereka langsung melihat hasilnya sehingga budidaya lebah ini memiliki peluang yang baik untuk lebih dikembangkan terutama pada masa pandemi dimana masyarakat membutuhkan madu sebagai salah satu asupan untuk memperkuat imunitas tubuh.

\section{KESIMPULAN}

Kegiatan PEMBERDAYAAN MASYARAKAT TALANG MAMAK MELALUI BUDIDAYA KELULUT MENUNJUKKAN PERKEMBANGAN YANG BAIK. HAL INI TERLIHAT DARI MENINGKATKATNYA JUMLAH PRODUKSI MADU YANG BERBANDING LURUS DENGAN JUMLAH PENDAPATAN YANG DIPEROLEH. AKAN TETAPI, SIKAP MASYARAKAT YANG KURANG FOCUS DAN BELUM MENGETAHUI TEHNIK PEMASARAN YANG EFEKTIF MERUPAKAN SUATU TANTANGAN DALAM KEBERHASILAN KEGIATAN INI.

\section{DAFTAR PUSTAKA}

Antoko, B.S., Kwatrina, R. T., and Suryatmojo, H. 2006. Keragaman Jenis Hayati Dan Pengelolaan Kawasandi Resor Granit, Taman Nasional Bukit Tigapuluh, Riau. Jurnal Penelitian Hutan dan Konservasi Alam, 3(5), 513-532.

Eltz, T. 2001. Ecology of Stingless Bee (Apidae, Meliponini) in Lowland Dipterocarp Forest in Sabah, Malaysia, and An Evaluation of Logging Impact on Populations and Communities. Universtat Wurzburg. Munchen.

Erwan, and Yanuartati, B. Y. E. 2012. Breeding of Queen Bee and Farm Business Developing as Business Activity at the Beekeepers Group in West Lombok Regency. Mataram.

Kek, S. P., Chin, N. L., Yusof, Y. A., Tan, S. W., and Chua, L. S. 2018. Classification of entomological origin of honey based on its physicochemical and antioxidant properties. International Journal of Food Properties, 20(3), S2723-S2738. https://doi.org/10.1080/10942912.2017.1359185 
Kerisna, V., Diba, F., and Wulandari, R. S. 2019. Identifikasi Jenis Lebah Trigona spp. pada Zona Pemanfaatan Hutan Desa Menua Sadap Kecamatan Embaloh Hulu Kabupaten Kapuas Hulu. Jurnal Tengkawang, 9(2), 82-91.

Mello, B. C. B., and Hubinger, M. 2012. Antioxidant Activity and Polyphenol Contents in Brazilian Green Propolis Extracts Prepared with The Use of Ethanol and Water as Solvents in Different pH Values. International Journal of Food Science Technology, 47, 2510-2518.

Melyana, M., Yoza, D., and Arlita, T. 2015. Interaksi Sosial Ekonomi Masyarakat Terhadap Kawasan Taman Nasional Bukit Tiga Puluh (Studi Kasus Desa Rantau Langsat Kecamatan Batang Gansal Kabupaten Indragiri Hulu Provinsi Riau). JOM Faperta, 2(2), 1-8.

Michener, C. D. 2013. The Meliponini. In Pothoney: a Legacy of Stingless Bees (Eds. P. Vit, S. R. M. Pedro and D. W. Roubik) (pp. 1-17). New York: Springer Verlag.

Noor, M. 2018. Pemberdayaan Masyarakat. Dedikasi: Journal of Community Engagment, I(2), 87-99. https://doi.org/10.31227/osf.io/weu8z

Pribadi, A. 2020. The Influence of Vegetation Compositions on Asian Giant Honey Bee ( Apis dorsata Fabr.) in Kampar Regency. IOP Conference Series: Earth and Environmental Science, 533, 012045. https://doi.org/10.1088/1755-1315/533/1/012045

Pribadi, A. 2020. Produktivitas Panen Propolis Mentah Lebah Trigona itama Cockerell (Hymenoptera: Apidae) Menggunakan Propolis Trap dan Manipulasi Lingkungan di Riau. Majalah Ilmiah Biologi Biosfera: A Scientific Journal, 37(2), 60-68. https://doi.org/10.20884/1.mib.2020.37.2.1045

Pribadi, A., and Wiratmoko, M. E. 2019. Karakteristik Madu Lebah Hutan (Apis dorsata Fabr.) dari Berbagai Bioregion di Riau. Jurnal Penelitian Hasil Hutan, 37(3), 185-200.

Purnomo, Pribadi, A., Janneta, S., dan Suhendar. 2012. Tehnik Produksi Raw Propolis Lebah Trigona Itama dengan Modifikasi Kotak dan Lingkungan. Kuok.

Sakagami, S. F., Inoue, T., and Salmah, S. 1990. Stingless Bees of Central Sumatra. In S. F. Sakagami, R. Ohgushi, \& D. W. Roubik (Eds.), Natural History of Social Wasps and Bees in Equatorial Sumatra. Sapporo: Hokkaido University Press.

Samsoedin, I., dan Pramono, I, B. 1996. Studi Kemungkinan Perluasan Areal Taman Nasional Bukit Tiga Puluh di Provinsi Jambi. Bogor.

Shamsudin, S., Selamat, J., Sanny, M., Shamsul Bahari, A. R., Jambari, N. N., and Khatib, A. 2019. A Comparative Characterization of Physicochemical and Antioxidants Properties of Processed Heterotrigona Itama Honey From Different Origins and Classification By Chemometrics Analysis. Molecules, 24(21), 1-20. https://doi.org/10.3390/molecules24213898

Taman Nasional Bukit Tiga Puluh. 2017. Taman Nasional Bukit Tiga Puluh: Keanekaragaman dan Pesona Bukit Tiga Puluh. Rengat: Taman Nasional Bukit Tiga Puluh.

TFCA-Sumatera. 2016. Taman Nasional Bukit Tiga Puluh. Retrieved September 23, 2020, from http://tfcasumatera.org/bentang alam/taman-nasional-bukit-tiga-puluh/

Wiratmoko, M. D. E., and Pribadi, A. 2020. Physicochemical Characteristics of West Sumatera's Forest Honey. IOP Conference Series: Earth and Environmental Science, 415(1). https://doi.org/10.1088/1755-1315/415/1/012015 